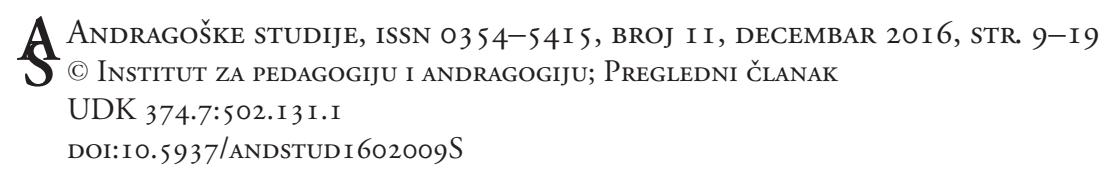

Ashley Stepanek Lockhart ${ }^{1}$

University College London, UK

\title{
Unpacking an Over-packed Agenda for the Marginalized: Problematizing Sustainable Development Goal 4, Targets 4.6 and 4.7
}

\begin{abstract}
This article describes and analyzes two issues related to Sustainable Development Goal 4, Targets 4.6 and 4.7. The first concerns assumptions and simultaneous commitments made regarding marginalized people and whether it is possible to achieve so much in just 14 years. The second concerns whether elements of equality and social justice are lost through how Target 4.7 is normatively conceived, as drawn out through a lens of post-colonial theory. A sample of programs from the UNESCO Institute of Lifelong Learning's LitBase is described and analyzed based on relevance to literacy and areas of global citizenship and sustainability. These programs are from three countries in three different regions of the world: Morocco, Mali and Georgia. While indications appear on track with targets based on how and what these programs reportedly teach, approaches taken and resulting outcomes, independent study is needed. How debates in post-colonial theory are being dealt with in reference to deeper, more critical aspects of global citizenship and sustainability, specifically "North-South" relations, power, identity and (neo)colonialism, also needs clarification. What is transformative about the SDGs, particularly Goal 4, depends on it and soon.
\end{abstract}

Keywords: Adult literacy, marginalization, global citizenship, sustainability, GCED, ESD, post-colonial theory, SDG4, Target 4.6, Target 4.7.

\section{Introduction to SDG4}

The post-2015 international education and development agenda is outlined in the Sustainable Development Goals (SDGs), specifically SDG4. This goal commits countries and the international community to "ensure inclusive and eq-

\footnotetext{
${ }^{1}$ Ashley Stepanek Lockhart is a consultant in global and comparative education and development (ashley_
} stepanek@yahoo.com). 
uitable quality education and promote lifelong learning opportunities for all" (UNESCO, 2015a, p. 8).

This ambitious goal and 10 targets were committed to at the World Education Forum in Incheon, Republic of Korea, during May 2015. UNESCO member states formally adopted what came out of the forum and developed into the Incheon Declaration for Education 2030 that following November. A broad base of stakeholders, ranging from international agencies/organizations, country governments, civil society actors and others contributed to what became the declaration. It was also operationalized to the Education 2030 Framework for Action for planning on strategy, implementation and tracking.

This agenda has been celebrated for its inclusive, collaborative formulation process, reportedly leading to expansive and diverse stakeholder buy in, and signaling the transformative intent of the goal and broader SDG framework. However, for the purposes of this article, SDG4, Targets 4.6 and 4.7, have come under review in various policy, practice, and research circles concerning the population where they overlap, which has characteristics of inequality and poverty that point to systematic marginalization. While these targets were created to help alleviate social problems over time and through different means, with particular attention given to this group in terms of social development, the question is if they are fit for purpose. Or if the operational response generated by the targets, in the form of interventions, are a match to what is warranted. Or maybe it is a combination of both questions.

\section{About Targets 4.6 and 4.7}

Some of the SDG4 targets (three of which are means of implementation) relate to marginalized youth and adults, with a few examined in this article. One is Target 4.6: "By 2030, ensure that all youth and a substantial proportion of adults, both men and women, achieve literacy and numeracy" (UNESCO, 2015a, p. 19). The other is Target 4.7:

By 2030, ensure that all learners acquire knowledge and skills needed to promote sustainable development, including, among others, through education for sustainable development and sustainable lifestyles, human rights, gender equality, promotion of a culture peace and non-violence, global citizenship and appreciation of cultural diversity and of culture's contribution to sustainable development. (UNESCO, 2015a, p. 20) 
Targets 4.6 and 4.7 were adopted in response to unmet commitments of the Millennium Development Goals (MDGs) and Education for All (EFA) to reduce social inequality and poverty for the marginalized. Target 4.6 addresses the approximately 757 million adults (ages 15 and above) unable to functionally read and write in a dominant or state-based language, two thirds being women (United Nations, 2015). Target 4.7, arguably more complicated and less clear in concept, application and follow up, promotes global citizenship education (GCED) and education for sustainable development (ESD), along with subareas and adjectival educations historically and concurrently provisioned, such as development education, global learning, human rights education, environmental education, etc. (Stepanek Lockhart, 2016, pp. 5-6).

Helping people to achieve a functional level of literacy is both a public good and a right. It enables people to engage with the knowledge community, and can lead to their heightened participation in society in ways related to personal interests, capabilities and choices. However, literacy has also become a means to other development priorities, based on documented benefits that "include greater participation in the labour market, delayed marriage, and improved child and family health and nutrition; these, in turn, help reduce poverty and expand life choices" (UNESCO, 2015a, p. 19).

However, some worry that literacy and numeracy are becoming over-packed and crowded out with expanded versions of themselves as vehicles for other development objectives. The concern is the basic, more traditional learning aim of the "three Rs"- "reading, 'riting and "rithmetic"-becomes secondary in the process to things like financial literacy, political literacy, digital literacy, global literacy, etc. The combined targets of 4.6 and 4.7 is an example of a possibly unreasonable set of learning aims set by the international community for the related overlapping population, when considering they are to be achieved in less than 15 years. Another concern is the social justice implications of Target 4.7, which on the surface reads positively, but upon deeper reflection is normative and therefore contentious. Debates in post-colonial theory help to draw out this angle more thoroughly.

\section{Postcolonial Theory}

GCED, and merging at some points with themes in ESD, encapsulate the only strand of education and formal learning that focuses on "North-South" relations (Andreotti, 2006, p. 7). This makes them seemingly obvious forums for discussions about "power, politics, identity and culture" along with issues of interdependence, inequality and marginalization, essential concepts in post-colonial the- 
ory (Andreotti, 2006, p. 7). But a lack of these discussions being had in GCED and ESD, particularly in animating international education policy discussions and commitments, indicates the need for more focus on developing principles that these subjects operate from.

Post-colonial theory draws out some of the deeper issues and debates that arguably should come up in GCED and ESD, especially if they are to be transformative. In essential terms, these set of debates:

- problematizes the representation of the Third World and issues of power, voice and cultural subordination/domination,

- questions notions of development and visions of reality that are imposed as universal,

- recognizes the violence of colonialism and its effects, but also acknowledges its productive outcomes,

- questions Eurocentrism, charity and 'benevolence',

- also questions issues of identity, belonging and representation, and the romanticisation of the South. (Andreotti, 2006, pp. 7-8)

GCED and ESD are supported by post-colonial theory in two main ways. One way is by "triggers for critical engagement" through the central concept of "alterity' - or the construction of identities and 'otherness" (Andreotti, 2006, p. 8). This looks at the construction of the self in relation to others, and the process of othering people through incorrect assumptions that serves a narrative of superiority and the far-reaching implications that can have (Andreotti, 2006, p. 8). Another way is by providing "an educational agenda that promotes a notion of citizenship that takes account of the cultural and material effects of uneven globalization" (Andreotti, 2006, p. 8). This agenda includes promoting "an ethical relation with the South" through "critical literacy, 'unlearning privilege', learning to learn from below, and learning to live with uncertainty" (Andreotti, 2006, p. 8).

\section{Two Issues}

Of specific issue are the simultaneous commitments to targets over the next (just!) 14 years that may coincide with other commitments unaccounted for outside of education and development, and the deeper issue of social justice when looking at Target 4.7. These targets are problematized and expanded upon:

i. out of practical concern for how current interventions attempt to address both targets, and whether they do so effectively and within a relatively brief timeframe; 
ii. out of conceptual concern that the transformative intent behind the targets, the goal and larger framework is diminished, or even lost, when contents of Target 4.7 (typically categorized as GCED and ESD) are seen as normative.

Based on the assumption that those without literacy in a dominant or state-based language are also missing GCED and ESD, the practical issue stemming from (ii) is that "alternative" or "indigenous" GCED and ESD knowledge and skills possessed by the overlapping population will go unrecognized. This could lead to tension between the international community and countries, along with tension within countries, based on political commitments to a specific kind of GCED and ESD articulated in Target 4.7, and pre-existing versions at subnational, regional and local levels.

While Target 4.7 promotes inclusion and equity in access to education and attainment in learning, especially for the marginalized (UNESCO, 2015a, p. 6), there is a possibility that GCED and ESD knowledge and skills exhibited by marginalized people, but called by a different name or characterized or articulated differently based on a different (meaning non-Western, or "Southern") social history and context, will be overlooked. The emerging concern is three-fold: if countries implement Target 4.7, it could challenge the equity of these contributions, and we potentially lose valuable lessons on historical and current approaches to GCED and ESD existing on the periphery from knowledge systems and cultural heritages of marginalized people.

The other emerging concern is that marginalized people will be treated as "empty vessels" to fill with Western-derived notions of GCED and ESD knowledge and skills, as appears to be the current articulation in Target 4.7 - what could amount to a neocolonial project. As such, if typified by this kind of assumption, the transformative aspect of Education 2030 falls into question, as does any notion of quality and shared "ownership" of these subjects by learners based on their local, situated, contextualized and/or indigenous knowledge systems and practices.

To suss out the danger of these assumptions, post-colonial theory is a useful lens for examining whether power imbalances exist in the current interpretation of the framework for these learners, and if this could serve to reproduce inequalities. It is used in the following sample analysis of relevant programs taken from LitBase, UNESCO's Effective Literacy and Numeracy Practices Databases, which is managed and hosted by the UNESCO Institute of Lifelong Learning (UIL). The other concern about over-packed, simultaneous commitments to literacy and GCED and ESD is also touched on in looking at this sample. 


\section{Sample analysis}

Programs were searched for on UIL's LitBase relating to adult literacy, GCED and/or ESD, by key words and categorizations such as "citizenship" and "sustainable development," along with content analysis of themes and relevant categories. These resulted in the following programs located in three countries in three different regions of the world. Only one of the three programs matches the three categories. Many other subjects are also covered in the content, such as law, fair trade, accountancy, micro-finance, gender, etc., some of which is included in the following:

- Morocco: The Functional Literacy Programme of Women of the Argan Cooperative through Amazigh (Berber) Language DVDs has been going since 2008 and focuses on literacy and aspects of ESD. It centers on the Argan forest which is a biosphere, the trade the oil provides, especially for rural women as the main workers, and the importance of environmental protection "to promote and demonstrate a balanced relationship between people and nature" (UIL-LitBase). It operates in five provinces in Souss Massa Draa, a region in central Morocco. ${ }^{2}$

- Approach: Participatory methods are mainly used, along with brainstorming to give space for debate with the hope of cooperation. This "is followed by the use of audio-visual material on the same theme. As this material is in the mother tongue ... they are able to follow it closely and also understand it. The content projected during the showing is then used to rectify, where necessary, some of the women's ideas or viewpoints expressed during the preliminary discussion while continuing to promote free expression" (UIL-LitBase);

- Timeframe: Classes are held six months of the year with an average of 25 learners per group.

- Mali: The Community Development Progamme addresses literacy and citizen rights and responsibilities and development connected to Reflect literacy centers. Other issues it addresses are child trafficking, child survival, reproductive and sexuality education, along with savings and credit schemes. The target group is "women, men, schoolchildren, outof-school children and local councillors in the communities of Sibirila, Yinindougou and Kouroulamini in Sikasso" (UIL-LitBase). ${ }^{3}$

\footnotetext{
${ }^{2}$ http://www.unesco.org/uil/litbase/?menu=4\&programme= 148

${ }^{3}$ http://www.unesco.org/uil/litbase/?menu=4\&programme $=3$
} 
- Approach: The programme's "conceptual model is founded on the values and principles of adult education, which encompass knowledge, expertise, interpersonal skills, participation and empowerment" (UIL-LitBase). Stepping Stones and Reflect (STAR) are utilized: "Reflect combines the tools and techniques of participatory research with communication techniques that follow the philosophy of Paulo Freire, while Stepping Stones is a communication and training tool, again based on participatory methods, which was developed to address the vulnerability of young people and women with regard to decisions about their sexuality" (UIL-LitBase).

- Timeframe: Learning circles are created in villages in which the program operates. These circles typically comprise around 30 people, each with responsibilities and a desire to learn how to read and write for other pursuits. Circles meet several times per week and the participants decide how often.

- Georgia: The Adult Education Centres in Samtskhe-Javakheti provides interventions for literacy, democratic citizenship, sustainable development, as well as life skills, health, gender, income generation, poverty alleviation, ICT, etc. to ethnic minorities, mainly Armenian and Azeri. ${ }^{4}$

- Approach: "A variety of modern interactive methods of adult education such as lectures, presentations followed by discussions, group work, role playing, facilitated discussions, brainstorming are used during the training activities at the AECs" (UIL-LitBase).

- Timeframe: Interventions through different course training run from one to four months.

While it is hard to tell much about timeframe from these case study summaries, aside from them all being six months or less, with regard to (ii) mentioned earlier, specifically whether current interventions address both Target 4.6 and 4.7, it appears that all programs address literacy. They provide methods for learners to read and write, and how to consolidate their literacy. But as far as GCED and ESD, each program has a partial answer that seems contextualized to the respective case.

The Morocco program is focused on women and their connection to nature through environmental protection of the Argan Forest. Malis program tends towards civic education and understandings of rights and responsibilities of citizens

\footnotetext{
${ }^{4} \mathrm{http} / /$ www.unesco.org/uil/litbase/?menu=4\&programme $=60$
} 
and extensions of that. The program in Georgia provides interventions for all three. However, one must ask about the feasibility of all three being taken in equally, or rather in a way that promotes learning of all aims and results in viable outcomes. We know they are not necessarily taken in equally in Georgia's program, when in another part of the summary it states that students focus more on computer courses and others related to digital technology. Each program also has other intervention areas, beyond those alluded to in Georgia: Morocco's has fair trade, Mali's has child protection and sexuality education, and savings and credit schemes. Georgia's has it all: life skills, health, gender, income generation, poverty alleviation, etc.

The question is whether these programs teach these topics and subjects well or not in relatively brief timelines. It is hard to get a sense of whether they are effective from the case study summaries. They are claimed to be effective, though we do not fully know the nature of the reporting chain and how the programs were assessed, aside from self-assessment and donor/financier assessment. In terms of timeframe, typically an effective literacy program offers consistent provision to a cohort for two to three years. None of the summaries indicate this length of time. In Georgia, it is a matter of months, Mali's timeframe appears to really depend on the learner, and Morocco is six months. We are not clear how much of this is literacy, and whether the cohort can choose to continue longer, or in another or more advanced cycle. Not accounting for Mali, the other timeframes are brief but are not sure to be effective, thus calling into question the effectiveness of the interventions.

The teaching and learning methods used in the programs could be another way that aspects of GCED and ESD are promoted and taken in, beyond the subjects taught. The methods described in the case summaries suggest fair and dynamic processes of dialogic learning through discussion, reflection and reconsideration. For example, Morocco's program is described as participatory and uses brainstorming, Mali's program uses Reflect and STAR, and Georgia has interactive methods. But beyond this and what it signals in theory, it is hard to tell if the post-colonial debates presented earlier are addressed and taken up in approach and content.

\section{Conclusion}

It is useful to scope out a sample of what programs are doing related to literacy, GCED and ESD, in connecting back to Targets 4.6 and 4.7. But what this exercise provides is merely preliminary and suggestive of further directions to inquire. Independent, direct study of these programs is needed for evaluation of learning 
aims and processes, but also in terms of outcomes and wider effects as part of a larger study of how they are attempting to answer SDG4, Targets 4.6 and 4.7.

The three programs reviewed indicate brevity in timeline, along with literacy, and GCED and ESD subjects and methods. Based on this, these programs may be able to meet the 2030 call and deadline. But this is problematized when looking at whether and how programmatic learning aims are translating to real outcomes and extended activities that show increases in literacy, global citizenship and sustainability. With regard to post-colonial debates and the more critical, probative topics and themes they encapsulate, such as "North-South" relations, power, identity and (neo)colonialism, the depth and form of GCED and ESD is in question and remains to be seen.

If learning is to lead to the transformation that we all hope for in the SDGs, especially Goal 4's "inclusive and equitable quality learning" for marginalized people over their lifetime, these debates will have to be addressed and taken up soon.

\section{References}

AndReotTi, V. (2006). Theory without practice is idle, practice without theory is blind: the potential contribution of post-colonial theory to development education. $D e-$ velopment Education Journal, 12(3), 7-10.

Andreotti, V. \& T. M. De Souza, L. M. (2008). Through Other Eyes Resource Pack. Derby: Global Education. Retrieved from http://www.maailmakool.ee/wp-content/uploads/2015/08/resource-UK-through-other-eyes.pdf

Biccum, A. (2010). Marketing development: a 'new' national narrative' in Global Citizenship and the Legacy of Empire: Marketing Development, (50-75). London: Routledge.

Bourn, D. (2014). The Theory and Practice of Global Learning, DERC Research Paper No. 11, London: IOE.

DAvies, L. (2006). Global citizenship: abstraction or framework for action? Educational Review, 58(1), 5-25.

Hoppers, C. A. (2009). Development Education at the Transition from the Modern Triage Society to a Moral and Cognitive Reconstruction of Citizenship. Keynote Address to the International Conference on 'Critical Thinking And Development Education: Moving from Evaluation to Research', 3-4 October 2009, National University Of Galway, Ireland.

Scheunflug, A. \& Asbrand, B. (2006). Global education and education for sustainability. Environmental Education Research, 12(1), 33-46.

Stepanek Lockhart, A. (2016). Non-formal and informal programs and activities that promote the acquisition of knowledge and skills in areas of Global Citizenship 
(GCED) and Education for Sustainable Development (ESD). Background paper commissioned for the Global Education Monitoring Report 2016, Education for people and plant: Creating sustainable futures for all. Paris, UNESCO.

Unesco Institute of Lifelong Learning (UIL). UNESCO's Effective Literacy and Numeracy Practices Database (LitBase). Retrieved from http://www.uil.unesco.org/ literacy/effective-practices-database-litbase

United Nations Educational, Scientific and Cultural Organization (UNESCO) (2014). Roadmap for Implementing the Global Action Programme on Education for Sustainable Development. Retrieved from: http://unesdoc.unesco.org/ images/0023/002305/230514e.pdf

United Nations Educational, Scientific and Cultural Organization (UNESCO) (2015a). Education 2030: Incheon Declaration and Framework for Action-Toward inclusive and equitable quality education and lifelong learning for all. Retrieved from: http://www.uis.unesco.org/Education/Documents/incheon-frameworkfor-action-en.pdf

United Nations Educational, Scientific and Cultural Organization (UNESCO) (2015b). Global Citizenship Education: Topics and Learning Objectives. Retrieved from: http://unesdoc.unesco.org/images/0023/002329/232993e.pdf

United Nations Educational, Scientific and Cultural Organization (UNESCO) (2016). Global Education Monitoring Report 2016, Education for people and plant: Creating sustainable futures for all. Retrieved from: http://unesdoc.unesco.org/ images/0024/002457/245752e.pdf 
Ashley Stepanek Lockhart ${ }^{5}$

Londonski univerzitetski koledž, Velika Britanija

\section{Raspakivanje programa za marginalizovane grupe: problematizacija potcilja 4.6, potcilja 4.7 i četvrog cilja za održivi razvoj}

Apstrakt: Ovaj članak se bavi opisom i analizom dvaju pitanja koja se tiču potciljeva 4.6 i 4.7, u okviru četvrtog cilja za održivi razvoj. Prvo pitanje se tiče pretpostavki i u isto vreme postavljenih obaveza u odnosu na marginalizovane grupe, kao i mogućnosti da se sve to postigne za samo 14 godina. Drugo pitanje se tiče toga da li su elementi jednakosti i socijalne pravde izgubljeni u normativnoj konstrukciji potcilja 4.7, posmatrano u okviru postkolonijalne teorije. Za potrebe članka, izvršeni su opis i analiza na uzorku programa iz LitBase-e UNESCO Instituta za celoživotno učenje, na osnovu njihove relevantnosti za pismenost i oblasti globalnog građanstva i održivosti. To su programi koji se sprovode u tri zemlje iz tri različita svetska regiona: Maroku, Maliju i Gruziji. Iako indikatori deluju usklađeni sa ciljevima u smislu sadržaja i metoda tih programa, njihovih pristupa i ishoda, nalazimo da treba dalje istraživati. Takođe treba razjasniti odnos programa prema debatama koje se vode u postkolonijalnim teorijama u vezi sa dubljim i kritičnijim aspektima globalnog građanstva i održivosti, naročito relacijama 'sever-jug', odnosima moći, identitetima i (neo)kolonijalizmom. Od toga, i to u skoroj budućnosti, zavisi transformativna priroda Ciljeva za održiv razvoj, posebno četvrtog cilja.

Ključne reči: pismenost odraslih, marginalizacija, globalno građanstvo, održivost, obrazovanje za globalno građanstvo, obrazovanje za održivi razvoj, postkolonijalne teorije, četvrti cilj obrazovanja za održivi razvoj, potcilj 4.6, potcilj 4.7.

\footnotetext{
${ }^{5}$ Ashley Stepanek Lockhart je konsultant za obrazovanje i razvoj na globalnom nivou.
} 